\title{
REINVIGORATING CULTURAL LANDSCAPES FOR PLANNING CULTURAL TOURISM IN BALI
}

\author{
I Made ADHIKA \\ Udayana University, Engineering Faculty, Department of Architecture, Bukit Jimbaran Campus, Bali, Indonesia, 80361, email: adhika@unud.ac.id \\ I Dewa Gede Agung Diasana PUTRA*
}

Udayana University, Engineering Faculty, Department of Architecture, Bukit Jimbaran Campus, Bali, Indonesia, 80361, email: diasanaputra@unud.ac.id

Citation: Adhika, I.M., \& Putra, I.D.G.A.D. (2020). REINVIGORATING CULTURAL LANDSCAPES FOR PLANNING CULTURAL TOURISM

IN BALI. GeoJournal of Tourism and Geosites, 33(4spl), 1462-1469. https://doi.org/10.30892/gtg.334spl03-594

\begin{abstract}
A cultural landscape, a configuration produced by human actions and cultural structures in a physical setting, has a significant role to play as a vital feature of cultural tourism in Bali. However, this configuration has become the most heavily commoditized ele ments of the development of tourism. Construction of tourist amenities has exploited the notion of a cultural landscape that has been integrated into cultural practices, the environment and agriculture. This development and planning are a paradoxical phenomenon and a challenge for pe ople to retain the identity of their cultural landscape while also seeking economic benefits from tourism. The struggle between the protection of the identity of the cultural landscape translated and manifested in the context of agriculture and its transformation in the context of designing tourist facilities has shaped the fundamental argument for preservation. Since there are different cultural traditions and practices in many Balinese cultural landscapes, the relationship between tourism and the diversity of cultural areas has become a key objective in the development of tourism and planning tourist facilities. This paper explores the current struggles between the concepts of tourism development and planning, and the conservation of Bali's cultural landscape. The paper argues that the focus of Bali's tourism development is to maintain and reinvigorate the integration of natural landscapes and cultural practices that present a persistent link between the agricultural system and religious practices.
\end{abstract}

Key words: reinvigorating, cultural landscape, human practices, tourism development, agriculture, religious traditions.

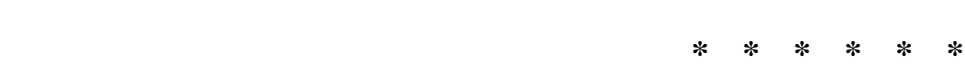

\section{INTRODUCTION}

The setting of the cultural landscape is shaped by human society and nature, representing an essential storehouse of natural and human cultural resources. This setting is a place for people to perform their activities in the environment to produce socio-cultural, economic and ecological configurations (Farina, 2000). In relation to this setting, Balinese belief that the earth belongs to God relates directly to the socio-religious activities and influences the ecological system has been discussed in many studies of Bali, such as those of Covarrubias (1974) and Goris (1984). Central to the faith is that there is the affiliation between the agricultural and spiritual system demonstrated in the daily life of the Balinese and their agricultural practices. This relationship is the Balinese's icon attraction, the vital resources of its tourist products. Throughout the latest three decades, the tourism economy has created new economic powers and has transformed landscapes of the world, including Bali. The planning and development of tourist destinations in Bali, the most famous tourist destination in Indonesia, in general, does not yet have a comprehen sive concept.

The development, which relies on culture and natural environment, tends to use original arrangements of the traditional forms that were traditionally just designed for local people activities and have not been designed for tourism. The spora dic development of tourist facilities has overburdened the existing physical landscape. This overburden development causes negative impacts not only for the environment, socio-culture and traditions but also for the traditional pattern of the settlement and urban areas (Burns, 2004; Putra, 2016; Putra, 2018; Putra, 2019). This current model of development also does not address the needs of unique tourist areas (Tosun a nd Jenkins, 1996) and ignores community participation (Kala and Bagri, 2018; Adiyoso, 2009). The construction is possibly transforming the traditional scenery and landscape being elements of a traditional identity as recourses of tourism development.

This transformation is a paradox phenomenon and the challenge for local people to maintain their identity while they also try to gain economic benefits from tourism. On the other hand, the commoditization of traditions for tourists was just as much a part of tourist attractions as separate landscape performances and people's cultural practices. The refore, the attractions have been not able to demonstrate integrated relationship between agriculture and culture in a cultural landscape system.

Therefore, this paper is to investigate the interrelation between cultural landscape and tourism planning and development to provide effective strategies to support the variation resources and reinvigorate cultural landscape for tourist destinations in Bali. This paper argues that negative influences of tourism on the culture and environment are resulted by the neglecting of the notion of a cultural landscape that integrated between nature and human practices. This paper then scrutinizes and explores how the tourist destin ations in Bali have been developed to gain economic benefits for the communities. This paper also examines how far tourism development can meet and address the unique requisites of a variety of tourist destinations in different regions of Bali. To do this, the art icle explores some tourist areas in Bali. It utilizes architectural investigation and spatial stories of communities' practices as a technique of examination.

In this paper, interviews and conversations with local people, plans, maps and photographs are used to establish a framework for the social, culture and tourism use of spaces to explore the role of cultural landscape concept for tourism development. Initially, however, the method used and some theoretical considerations of how the cultural landscape used in tourism planning and development are di scoursed. This section is followed by a comprehensive explanation of some tourist destinations in Bali to obtain a spatial-oriented tourism development pattern and review the general issues of the planning and development of tourism. In subsequent section, this paper discusses the diversity of cultural identity, environmental conditions and the effects of these variations on the approach of cultural landscapes in many tourist destinations. Conclusions are explained in the last section.

\footnotetext{
${ }^{*}$ Corresponding author
} 


\section{MATERIALS AND METHODS}

As a famous tourist destination in Indonesia, most tourism developments in Bali are in coastal areas and a few of them in the interior of the island. There are still many areas in Bali, especially the areas in the middle of the island called Bali Tengah that is located between mountains and lowlands (Pujaastawa et al., 2005). The cultural landscape in the area is the integration of the agricultural system and religious traditions in the highlands of the island. The people in this area use agricultural harvests to prepare food for their family, to sell the products in the market, and to perform rituals. On the other hand, people perform rituals by making offerings using agric ultural products to use in praying for good harvests, giving thanks to God, who gives people fertile lands. Factors that influence the sustainability of this Balinese agricultural system are the integration between agricultural and cultural activities of the people in a cultural landscape. Tourism in these regions, however, tends to rely solely on nature. In some cases, as people do their cultural tourism, the attractions are not combined between cultural and agricultural practices so that the attractions can not display the integrat ed relationship of culture and agriculture as part of the cultural environment. Therefore, in an attempt to investigate the cultural landscape in the Bali highlands, the villages in the middle of Bali called Bali Tengah, which differ cultures and spatial circumstances, were chose $n$ as the locations for this study; and the facets of cultural landscape become components of method used in this paper.

The method used in this paper is in three stages. The first stage is literature reviews about cultural landscape and tourism in which this stage is to produce the theoretical framework (Farina, 2000; Domosh, 2004) by investigating the meanings and characteristics of cultural landscape to design operational principles for tourism development (Utami, 2020; Utami, 2018). Descriptions and classification of the cultural landscape and cultural tourism, and their appropriate conceptions were also explored from explorations of related literature.

The second phase is to investigate the practical framework by creating appropriate features of the Balinese cultural landscape and its tourism development. The implementation and characteristics of tourism development in many tourism destinations in Bali were gained from published literature, visual examinations and spatial stories of communities' practices. Interviews and conversations with local people and photographs are utilized to investigate the socio-culture and tourism use of spaces (Putra et al., 2019) and to discover the role of cultural landscape concept for tourism development (Gordon, 2018). Critical analyses are then carried out to discover the impacts of tourist activities on the Balinese cultural landscape. The impacts are investigated from the implementation of cultural practices, the transformation of the traditional houses and village patterns (Samsudin and Maliki, 2015), and the components that have been commoditized, and explanations from tourists and local people. The final stage scrutinizes why cultural landscape is significant for cultural tourism in Bali.

In this term, the sustainability of tourism uses natural landscape resources and cultural characteristics to meet the visitors' requirements (Bentivenga et al., 2017; Cebrián and Sánchez, 2016). This step is also to investigate and create a prospective and possible strategy to reinvigorate cultural landscape for developing tourism products that are able to be applied in the highlands of the island.

\section{BALINESE CULTURAL LANDSCAPE AND CULTURAL TOURISM}

Cultural landscapes are well-defined as an arrangement that culture represents on the land (Salter, 1971; Birks et al., 1989; Domosh, 2004). The intricacy of the cultural landscape is represented in nature, culture, and economy, referring to food production, components in which there are harmonious relationships among the components (Farina, 2000). These components have interacted and integrated to produce the arrangement that can be seen as the evolutionary subsequence affected by human interaction in cultural activities (Myga-Piątek, 2011). In a cultural landscape, the cultural practices experience the continual alteration over time (Conzen, 2004) generally in the context of agro-pastoral activities (UNESCO, 2003; 2005). The dispersal ecumene occasionally stabilized and communities who occupied it controlled the new explored space, which was escorted by transformation as a part of sustainable development (Pawłowski, 2009). Therefore, a cultural landscape can be explained as the evolutionary image of developing people's talents and capabilities to utilize and alter the environment (Andreychouk, 2008) in a fusion of bio-physical and socio-cultural ways in an ecological cycle (González, 2020). The transformation has produced various montages of natural settings and has gotten many scientific categorizations (Pietrzak, 2005; Degórski, 2005; Gordon, 2018).

The integrated affiliation between the culture of communities and natural settings in the landforms has generated a unique cultural landscape. In this unique relationship, people and the landscape interdependently live in which they exist because of the others (Buckley et al., 2008) in which landscapes reflect the cultures that generated them (Zhang and Taylor, 2019). This notion not only produces unique places but also presents the daily spaces as places for people to live work (Meinig, 1979; Jackson, 1984) and spiritual creation (Hussain et al., 2020). Cultural landscapes represent daily life of communities that demonstrate the people's stories, occasions and locations across the times (Taylor, 2015). The people's sense in a cultural landscape represents genuine passions that assist and appropriate definite memories (Smith and Campbell, 2015). This cultural landscape is implemented in the Balinese religious philosophy in which the built environment is one of the manifestations of human traditions and cultures in a natural environment (Covarrubias, 1974).

For Balinese, the ground belongs to God and ancestors so that they generate a good connection with God, human beings and the environment. This relationship is the personification of the Hindu religion philosophy called tri hita karana (Kagami, 1988; Eiseman, 1989; Huang and Rockwell, 2019). The tri hita karana philosophy then encourages other ideas related to the Balinese landscape from the world physical division, including houses, villages, and regional patterns, to the human physical division, including humans, detail of building and building compositions (Putra et al., 2020). The philosophy presents the significant relationship between the agricultural system and religious traditions. In this system, agricultural products are used for food and for performing rituals, while ri tuals performed use agricultural products for good harvests and giving thanks to God. In this system, as stated by O'Hare (1997), the environment has been composed of a cultural overlay and modified, classified, and interpreted by the people to be their identity (González, 2020). The identity of a place originates from the collaborations between the natural and cultural components.

This system is expressed in the way of life of the Balinese and their agricultural systems. For this reason, their domestic a nd religious practices and their aim to maintain a harmonious relationship with God, other humans and the environment relate to agricultural sustenance and prosperity. The variety of agricultural products reflects the complexity of the microclimatic and edaphic characters of Balinese and this produces a variety of cultural practices. This system presents that the intricacy of the Balinese cultural landscape is represented in three central elements: culture, nature, and economy (Wardana, 2020) that are presenting in the natural envir onment and agricultural fields, temple, settlement patterns, market, the traditional houses and cultural activities (Figure 1). In a cultural landscape, cultural aspects maintain economy and nature (Farina, 2000; Wardana, 2020). These practices are parts of agricultural processes from cultivating agricultural land, planting various agricultural products, harvesting time that have been performed in natural en vironment and agricultural fields (Figure 1 (A), as well as selling the products to markets (Figure 1 (B) and using the products as offerings (Figure 1 (C). Many traditional practices are performed during the process of agricultural activities, including ceremony activities (in the agricultural land, temple (Figure 1 (D), granary in the house (Figure 1 (E), and market temple and traditional practices as the way to leisure time after harvesting time in the agricultural fields and in the village (Figure $1(\mathrm{~F})$. 


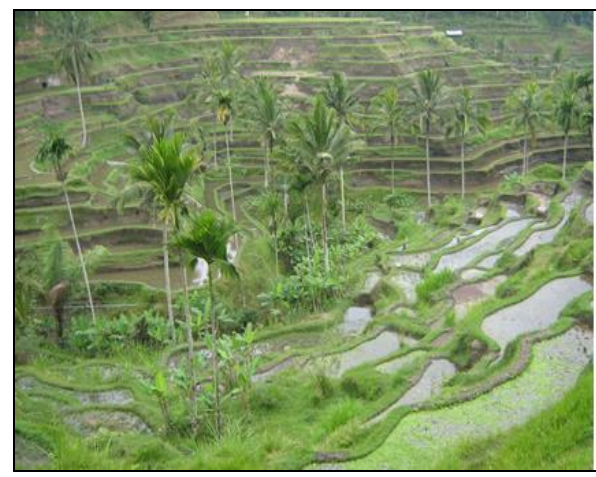

A. Natural environment and agricultural fields in Bali Area

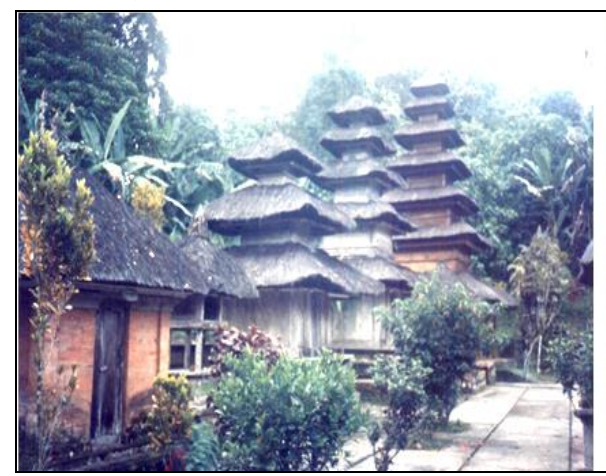

D. Batukaru Temple in Wongaya Gede Village

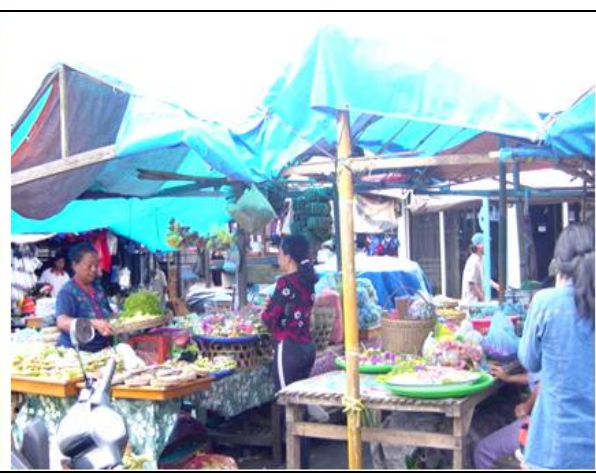

B. A market in Baturiti, Tabanan

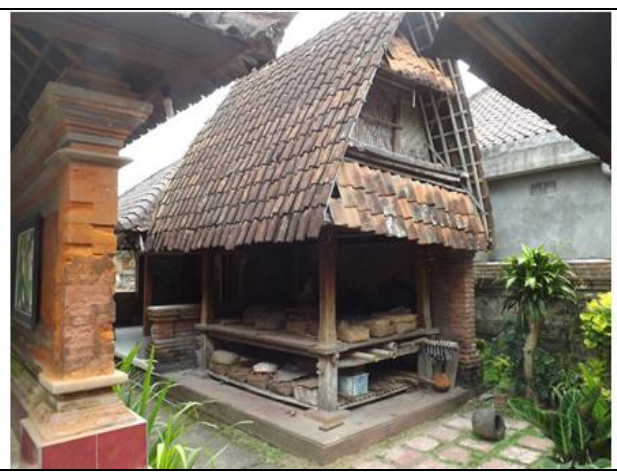

E. A granary in a house for storing un-hulled rice in Bali

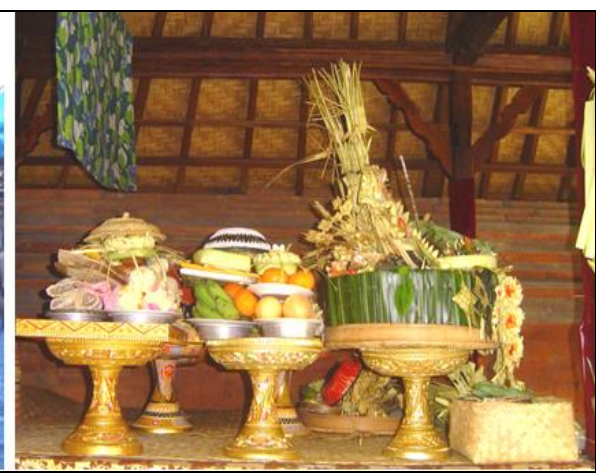

C. Offerings in a ceremony using agricultural products in Bali

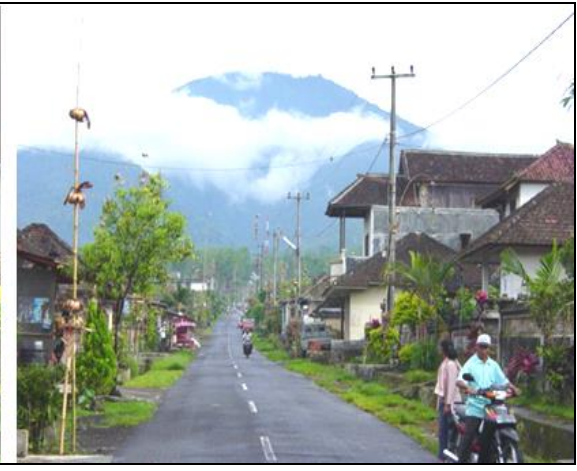

F. The traditional village of Wongaya Gede

Figure 1. The Cultural Landscape of Bali consisting of natural environment

(A), market (B), ceremonial activities (C), temple (D), a granary in a traditional house (E), and traditional village (F)

However, these iconic settings then bec0me resources to gain economic benefits from tourism. As a tourist attraction, the setting of a cultural landscape will have uniqueness because of culture, and the differences of culture are because of the landscape (Buckley et al., 2008). A motivation of tourists is not only to look for the natural environment, but also to search for exotic cultural prac tices consisting of artefacts, arts and other products or services of traditional communities (Yang et al., 2006). This phenomenon, known as cultural tourism, is defined as the mobility of people for principally cultural motivations including cultural and study tours, travel to witness art performance and other related events (World Tourism Organization, 2012). This phenomenon has then encouraged many countries to promote and try to maintain and invigorate their culture as assets to produce a center of tourist attention (Yang and Wall, 2009). Government and local engagement can improve the reinvigoration of cultural landscape (Chang et al., 2015). More critical is the development of a bottom-up model in the mobilization and consolidation of local actors (Liu, 2008).

Local actors have been cultural invigorators (Burton, 2012) and they have a role to play in maintaining the local culture and empowering people within their communities to work together to protect and sustain their local cultural environment. However, the cultural landscape, in which domestic and ceremonial practices are performed, has been transformed. The new additional function of the setting to serve tourists demonstrates a struggle between the preservation of cultural landscape and economic a spect. This is a paradoxical phenomenon in many cultural landscapes including Bali. As a product of alteration and non-static phenomenon, the Balinese landscape experiences a process of transformation, even though the people attempt to preserve and re-invigorate their traditions as an asset for tourism development. The interactions with foreign cultures and the unfolding transformation of social and cultural relations among the local people deeply influence the process of accepting a new tradition (Gusfield, 1967). The change of cultural landscape is a complex issue in which changes to the physical setting influence socio-religious practices and the environmental components of the natural setting. The change is an architectural challenge in which the challenge represents potential problems and gives rise to the question of the continuity of ceremonial practices and the interrelationship between the people and their cultural landscape. The close link between religious traditions and environmental elements is a demonstration of the traditional roles of spaces in the cultural landscape to accommodate the occupants' activities independently and to maintain cosmic harmony in the tourism economy. The potential problems in relation to the traditional roles of the cultural landscape in the tourism economy will be examined in the following section.

\section{TOURISM PLANNING AND DEVELOPMENT IN BALI: IGNORING THE NOTION OF BALINESE CULTURAL}

\section{LANDSCAPE}

Up until the 1900s, many villages, such as Singaraja, Gelgel, Klungkung, Kamasan, Kintamani, Badung, Gianyar, Sanur and Kuta, were identified as interesting places for visitors and researchers (Agung, 1991; Sprague, 1970; Vickers, 1989). In the follow ing years, other villages, such as Ubud, Tihingan, Kedaton, Sangeh and Candi Dasa, Tanah Lot, and Bedugul, were introduced as tourist destinations. In the new millennium, Nusa Dua, Sanur, Kuta and Ubud (Figure 2) have become the main tourist destinations and then have gotten more attention (Picard, 1996). Sanur was a traditional harbor and the access point of the Dutch attack to the kingdom of Badung. In the 1960s, it arose as the main tourist destination with big investments from foreigners and entirely closed to the indigenous societies (Picard, 1996). Kuta, on the other hand, was also a traditional harbor from 1597. In the 20th century, it emerged as a new tourist destination. In Kuta, tourist facilities were constructed and managed by local people so that it was quite united with the local communities, where the people opened their houses to serve tourists (Wood, 1980). As coastal tourism destinations, Sanur and Kuta have similar conditions. The use of public space, such as beaches, has changed the traditional value and meaning of their cultural landscape. 


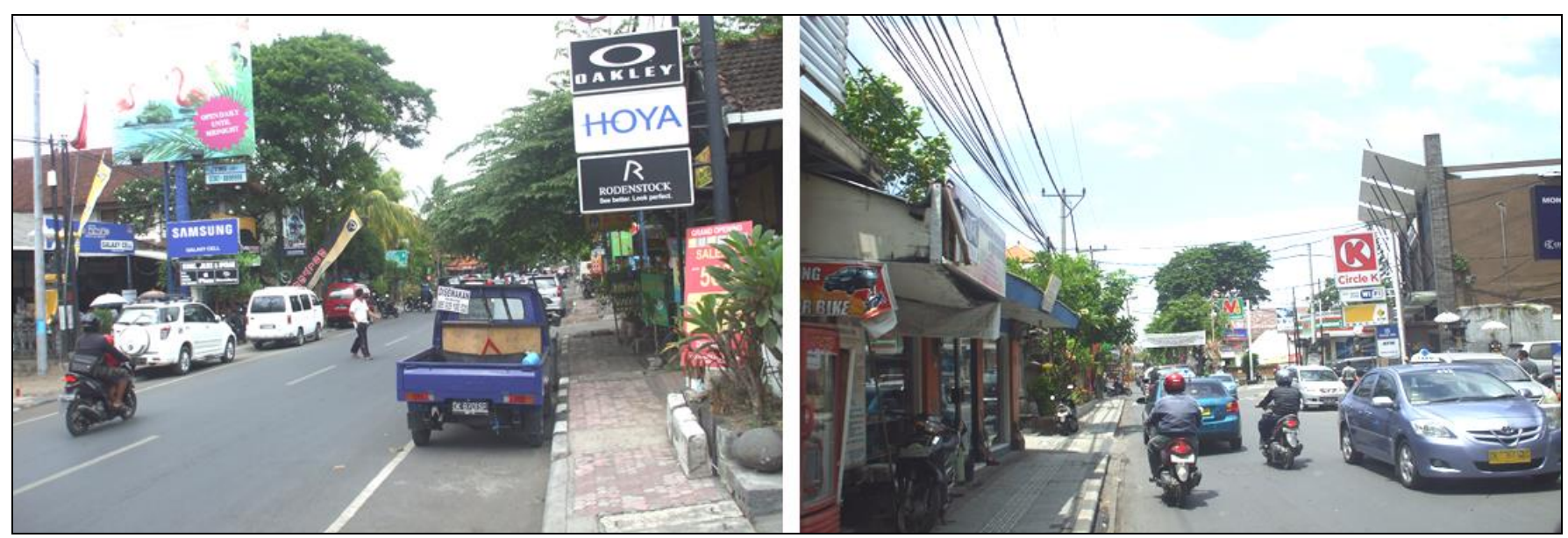

Figure 2. The most tourist facilities in the main road of Kuta-Bali

In the traditional pattern of coastal Balinese landscape, beaches were categorized as karang bengang that was the open spaces for ceremonial, agricultural or fishing activities. The economic activities were performed in markets located in the centers of the cultural landscape. These economic activities were around the places of human inhabitation where people performed socio-cultural, domestic and economic activities. In the past, each component (culture, economy and nature) interacted and had a harmonious relationship with the others. However, in the present-day, cultural aspects are weakly connected to other aspects (Farina, 2000). The economic elements have mostly contaminated cultural and natural elements. The beach that traditionally and culturally was a place for the purification ceremony now it also becomes the place for tourists to swimming and sunbathing. The cultural practices must share the space with touristic activities, in which, in some cases, there are conflicts between them. This conflict involves three values of interest orientation, including public interest, socially rooted and profit-making values (Chapin, 1957). Local people use the beach as their cultural and social values while the tourist activities on the beach can be seen as profit-making values. Some spaces, especially in front of some hotels, were restrictions for local people. However, after the long discussions and debates facilitated by local government, the Balinese communities can use the space for any activities by sharing to use the beach. Some restaurants or hotels have used the beaches next to their facilities by putting some chairs or swimming beds while people can use other parts of the beaches (Nurwasih and Wijaya, 2019; Adhika, 2012).

The phenomenon of economic elements pollution to other cultural landscape elements has also been experienced in the interior tourism destinations, including Ubud and Kintamani. Ubud was a traditional settlement where the villagers were actively involved in the tourism sector and utilized their social and religious practices as resources to attract tourists (Figure 3) (Picard, 1996). Kintamani is a high area that has the tourism potential of the caldera Mount Batur. This caldera has been reputable as a part of the Global Geopark Network and has become a tourist attraction that relies on the natural environment (Newsome et al., 2012; Jaafar et al., 2014).
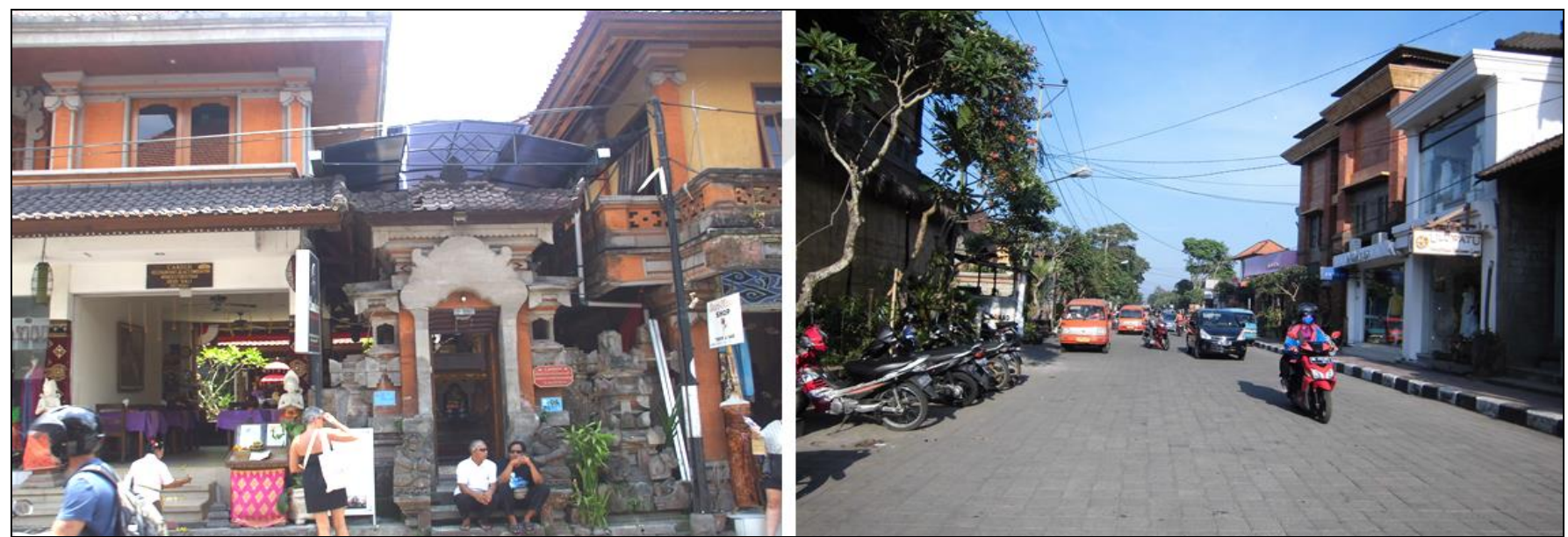

Figure 3. The traditional gate of the house in between tourist facilities (left) and the most tourist facilities in the road of Ubud Bali (right)

However, since the increase in the number of tourists, the beauty of Ubud and Kintamani that was able to be witnessed on-site by tourists now just can be seen in photographs, paintings or books. The use of land that is based on local rules has changed due to space demands to obtain the economic benefit of tourism by constructing many tourist facilities, such as kiosks, souvenir shops, bars, restaurants, hotels, and villas. On one side, there are limitations of spaces; on the other side, there are increases in land demand to accommodate tourist activities. The construction of tourist facilities has caused the transformation and elimination of the nuanced local spaces (Putra et al., 2019). These spaces are the identity of the local settlement such as the disappearance of the angkul-angkul (the traditional gate), telajakan (the garden between the road and the front wall of the traditional house), teba (the backyard) and karang tuang (the traditional green open space in the Balinese cultural landscape). The use of land has a limited capacity based on its carrying capacity. Land limitations cause the use of ravines, cliffs, and paddy fields that exist on the outskirts of the areas for the construction of hotels, villas, art shops and galleries. The new constructions have used the karang bengang (the undeveloped land) that traditionally was the place to sustain a harmonious relationship with the environment (Kagami, 1988; Eiseman, 1989; Dalem, 2007).

These constructions have produced less harmony with the nature of Bali, and at the same time, the tourism economy has polluted the cultural values and meanings of the traditional spatial impression. In this term, the role of the cultural aspects is ignored to screen the 
domination of economic aspects to natural aspects (Farina, 2000). Tourist facilities and infrastructure have been sporadically developed in which the area is mostly linearly developed along with the existing infrastructure and extended to other areas. It represents kotadesasi (the town-village mixed area) in which there is the growth of non-agricultural sectors in the area (McGee, 1989). Economic capital dominates the development and natural capital is just considered as merely tourist attractions (Farina, 2000). Different from tourist destinations mentioned above that were developed in the traditional settlement and actively involved local communities, Nusa Dua has been built in the empty land. Before the 1970s, just a few people occupied it for cultivating unirrigated lands, in which only temporary structures called $k u b u$ existed in the area. In this period, the number of tourists coming to Bali increased so that the government wants to anticipate these significant numbers by establishing an enclave of the tourism area in Bali (Picard, 1993; SCETO, 1971; IBRD/IDA, 1974; Wall, 1996). The development of an isolated tourism area was designed to reduce the negative impacts on the cultural landscape of Bali (Rodenburg, 1980). The tourism enclave is designed to obtain better spatial planning control and be able to empower the Balinese communities. In this way, the identity and development of the area are expected to address the spatial capacity and demands of the communities.

However, many studies of tourism have noted that the idea of the enclave is fundamentally unsustainable, marginalizing native businesspersons and spreading the economic, cultural and social gaps between hosts and visitors (Shaw and Shaw, 1999). The enclave tourism area, which is generally isolated from local people and daily life in the area, is inclusive (Freitag, 1994). Far from producing the area and the surrounding areas become a neat and a pleasant place for tourists and local people that accommodate the local socio-cultural practices. Rather the enclave becomes an exclusive place contrasting to its surrounding areas that sporadically develops, causing distress and irregularity. The tourism enclave becomes alien to the surrounding living space of the community. It shows and produces the economic gap between guests and dwellers as well as creates resentment and hostility in this paradox condition (Britton, 1982; Shaw and Shaw, 1999; Mbaiwa, 2005).

The previous tourism planning and developments in Bali have polluted the cultural landscape of Bali. Although the spaces in the landscape still accommodate most of the people's practices in relation to religious activities to maintain a harmonious relationship with God, the ancestors and other humans, the planning and development of tourism is not able to maintain the relationship of cultural practices and agricultural system in Bali. The cultural tourism in Bali has just been seen as cultural activities that are not interdependent with the agricultural system. The people still perform cultural activities using many kinds of agricultural products, but the agricultural products are from markets, and they have not produced and harvested agricultural products. The relationship between cultural and agricultural practices becomes an actual labor market. The relation between the agricultural system and the cultural system has altered to become profit-oriented and a calculated spirit related to the circulation of commodities (Appadurai, 1986; 2006). The new arrangement of the cultural landscape is unable to provide spaces associated with traditional ecological knowledge. The tourism development in Bali was unable to expresses the original Balinese cultural landscape characteristics, including symbolic meaning and hierarchy values associated with the movement of rituals.

The transformation of cultural landscapes in current tourism planning and development can be understood as a realistic reaction to accommodate new challenges in a community by reconfiguring the cultural landscape in Bali. This reaction is the challen ge of tourism development of Bali to preserve traditional practices, at the same time, obtain economic benefits from tourism.

As a concept, cultural landscapes have become a way to encourage sustainability in tourism development. The values of cultural spaces are significant to sustain and protect the natural environment, cultural practices, and economic resources (Samsudin and Maliki, 2015). Every tourism stakeholder should preserve the nation of cultural landscapes through designing tourism development based on the cultural landscape approach in Bali, including the middle areas of the island.

\section{THE CULTURAL LANDSCAPE IN THE BALI TENGAH}

The cultural landscape in the area of Bali Tengah is the incorporation of the agricultural and religious system. Because of the location in the highlands of Bali, the same parts of the area are sanctuaries and some of them are holy areas such as forests around mount Batukaru in Wongaya Gede. The function of these sanctuaries is water sources so that the existence and sustainability of the forests greatly influence the water supply in Bali. The geographic condition on the areas influences their landscape in which the areas have tropical forests, waterfalls, rafting, hot and acid water, such as in the traditional villages of Penatahan, Tengkudak, Wongaya Gede, Jatiluwih, Angsri, Baturiti, Petang, Plaga, and Melinggih. These geographic conditions are the potential to become tourist attractions.

As a part of cultural landscapes, the areas also have coffee, orange, clove, and irrigated rice fields. These plantations are found in almost all regions, where the dominant plantation areas are located in Petang and Plaga. The beautiful and well-known rice fields are found in some other villages such as Jatiluwih, Penatahan, Tengkudak, Wongaya Gede, Angsri and Baturiti (Agung et al., 2015; Yudhiantari, 2002; Herawati, 2015). The agricultural system of Bali uses subak as a traditional agriculture structural system. Subak manages many activities related to agricultural practices, including irrigation, plantation procession, and cultural activities (Pitana and Putra, 2013). The protected natural forests with a variety of biodiversity are found in villages such as Penatahan, Wongaya Gede, and Plaga, while the unique local forest is in Angsri. In this village, the bamboo forest has many species and has been managed using a traditional rule and has still been applied by the communities around the forests (Yeny et al., 2016; Arinasa, 2010). Hot spring is found in Penatahan and Angsri Villages, while acid spring water is found in Baturiti. Rivers that can be possible to be used as rafting place are found in Petang and Melinggih Villages.

The above-mentioned natural landscapes of the areas have also produced socio-cultural aspects. The areas have various socio-cultural artifacts and practices, including temples, holly springs and harvesting traditional performances. Many important temples for Balinese people are located in this area, including sad kahyangan and dang kahyangan temples. In these kinds of temples, Balinese people or other Hindu communities pray and pilgrim regularly (Sanjiwani and Pujani, 2019). The traditional procession of agricultural activities from planting the vegetation to harvesting the products has produced many cultural activities as a part of a dedication to God (Goris, 1984; Covarrubias, 1974; Reuter, 2002). Similar to other places in Bali, these cultural and ceremonial activities are related to the process of agricultural practices including ngendagin (the ceremony when the people are watering the land for the first time), ngurit (the ceremony before planting the rice), nyangket (ritual before harvesting the rice) (Putri, 2014). However, there are some unique traditions in this area, including megacikan, sanghyang dance (the dance while trance), and old jogged (traditional dancers of old people). Megacikan is the tradition to show the happiness of the people because they have already harvested agricultural products. This tradition uses okokan (traditional orchestra using buffalo necklace from wood) as the music instrument, (Pujaastawa et al., 2005; Hall, 2001).

As a part of cultural landscapes of the areas, these rituals are seen as ritual communication that is the way for the people to present their commitment to their tradition in their communities (Putri, 2014). Other cultural traditions, which are also coloring this cultural landscape and interesting for tourists, are the traditional settlements. The traditional settlement is a reflection of the pattern of life represented in the building, village and regional layouts. The traditional houses, especially in Penatahan, Tengkudak, Wongaya Gede, Jatiluwih, and Angsri, have many rice barns in various types, shapes, sizes, and layout. These models can not be seen in other villages. The shape and size of the barns can be used as a barometer to what extent the owner of the house has paddy fields and the amount of rice stored. 


\section{REINVIGORATING CULTURAL LANDSCAPE FOR PLANNING CULTURAL TOURISM IN BALI}

The cultural landscape aspects bringing tourists to Bali are the agricultural system and practices. Even though some other areas in Indonesia have a similar geographic and natural environment, but more tourists still prefer to visit Bali than elsewhere in Indonesia. For the tropical forest ecosystems, agricultural activities, or highland panorama of other places in Indonesia, for example, the primary attraction is the natural environment with the wild animals or agricultural activities (Riadi et al., 2018). These arrangements are only a minor proportion of the landscape. The agricultural and cultural activities of the people are not notable attractions; despite the fact, some visitors come to see them just for inquisitiveness or humanitarian motivations. In Bali, especially in the cultural landscape called Bali Tengah, the culture and landscape are interdependent. Tourism development, which relies on the natural environment and culture, has relatively fragile risks that can easily be negatively impacted by tourism (Yamashkin et al., 2020; Petrosillo et al., 2006). Therefore, the planning and development of tourism should be able to guarantee the sustainability of the natural environment as well as socio-cultural aspects (Astawa et al., 2019). Sustainability of the natural environment can be achieved by maintaining and improving the quality of the natural environment, regulating the use of spaces, preserving and conserving the sanctuary areas, improving the quality of natural resources that attract tourists and provide economic benefits for the community, and maintaining traditions of agricultural practices and reinvigorating the extinct traditions. However, the traditions performed for tourism should be not just as attractions that are unconnected performance with its cultural landscape. The cultural heritage should be performed as a part of the cultural landscape that is not just mere tourist performances (Buckley et al., 2008).

Therefore, in planning the land-use of tourism development as a part cultural landscape, the economic benefits ought to be obtained as part of the ecological system benefit that considerate human demand with ways to guarantee sustainable development (Wilson and Carpenter, 1999). In the reinvigoration process, the sustainability in plantation activities is the way to ensure the plantations' traditional system can be performed based on traditional rules and traditions following religious activities to produce good harvests. The improvement of the quality of plantations and invigoration of the cultural landscape can be an effort to attract tourists by presenting the plantation and post-harvest process. Tourists can involve in the plantation practices and post-harvest process both in traditional and current methods. The engagement of tourism in cultural activities can involve tourist's emotions that play a significant aspect to invigorate visitors' memorable experiences (Wright and Matthews, 2015, Hosany et al., 2015) rather than merely observing or witnessing the activities (Urry and Larsen, 2015). The passionate experience is a significant aspect to produce personal exclusive and astonishing experiences (Park and Santos, 2017). These activities are potent to attract tourists and a way to increase community aspects in a community (Munroe et al., 2014). This reinforcement is the way to ensure that the income of local communities, in which the reform of the market economy is a movement to reinvigorate culture, can obtain sustainable benefits for their agricultural products, their quality of life, and their ecological system (Rapport et al., 1998; Costanza et al., 1997).

The socio-cultural aspects of the community are greatly influenced by place, space, and time. Therefore, space plays an essential role in maintaining social and cultural sustainability and reinvigoration. Agricultural land as a place and spatial components are very instrumental significant to form the socio-cultural community (Buckley et al., 2008). The need to store agricultural products and the way to protect the product for a long time in the house have produced the setting of the traditional house and the structure of granary for storing agricultural products called jineng or gelebeg. This building can be an attractive artifact in the traditional house. This artifact can be a resource to attract tourists to stay in a traditional house by transforming the house to become homestay. In a homestay, tourists can witness the daily lifestyle of local people and enjoy the traditional house and its traditional agricultural system. In this system, the processes of planting rice including their ceremonial activities have also become attractive activities for tourists. Tourists can be actively involved in the activities while local people can perform their traditions not only as their dedication to the God and ancestor but also as a way to manage their economic activities. The additional actors namely tourists as an economic aspect in the Balinese agricultural practices, could be used to achieve sustainability of culture and nature in cultural landscape. In this term, integration between economic development and sustainable agriculture promotes the conservation engagement of local community to reinvigorate their cultural agricultural system (Borkhataria et al., 2012). However, in this system, cultural aspects have a role as filters to sustain environmental, economic, and cultural aspects (Farina, 2000).

In this system, the processes of planting rice, including their ceremonial activities, have also become attractive activities for tourists. Tourists can be actively involved in the activities while local people can perform their traditions not only as their dedication to God and ancestor but also as a way to manage their economic activities. The additional actors, namely tourists as an economic aspect in the Balinese agricultural practices, could be used to achieve the sustainability and reinvigoration of culture and nature in cultural landscapes. However, in this system, cultural aspects have a role as filters to sustain environmental, economic, and cultural aspects (Farina, 2000).

Cultural landscapes must be used as a strategy to analyze the scale of tourism destinations that are developed on the basis of the ability to adapt and reinvigorate the environment and culture. The development of tourist destinations would be planned on the basis of an integrated method between the three interdependent aspects of nature, culture and economy, in which culture is a vital component in ensuring not only the functionality of natural environmental systems and the sustainability of cultural practices, but also the maintenance of economic growth.

\section{CONCLUSION}

As the most famous tourist destination in Indonesia, the development of tourist destinations in Bali, in general, does not yet have a reliable concept to ensure the sustainability of cultural tourism. The development tends to influence the environment and cultural practices. Constructions of tourist facilities have possibly transformed the traditional scenery being the traditional Balinese identity. This identity is the main recourses of tourism development. This transformation becomes a paradox phenomenon and the challenge for tourism development in Bali, in which local people actively involved in tourism activities to obtain economic benefits from tourism by transforming some of their cultural resources. On the other side, they try to maintain their identity to attract tourists. The tourism planning and development in Bali has focused on the economic aspect that compromise to the transformation of culture and natural aspects.

This focusing tends to be unsustainable for the Balinese landscape and the Balinese society so that it is significant to investigate the new strategy for developing the sustainability of cultural tourism of Bali. Tourism plan and development processes, which transformed the natural landscape, are directly demonstrated by the local landscape narrative, and transform local landscape characteristics through the notion of cultural tourism focusing on economic aspects. Therefore, the transformation can be best explained as an ongoing adjustment where the cultural landscape of Bali is altered to address current economic demands. The recent tourism development is read as a practical reaction to accommodate new challenges in the community by reconfiguring the traditional Balinese landscape. The tourism economy giving economic benefit for local people could be utilized to reach the reinvigoration of the cultural practices and natural environment in which the cultural aspects have a role to filter for the sustainability of the other aspects. Since the increase of pride of the local people with their traditional cultures and heritage artifacts and the awareness of them in relation to the economic benefit of their culture, they now try to reinvigorate their culture and become gradually enthusiastic about showing their cultural landscapes as tourist attractions. Using cultural landscape as the vital element to construct tourism facilities becomes a strategy for Balinese to authorize their cultural uniqueness and identities. Cultural landscapes become a model and idea that can be applied in developing tourism. The integration and interdependent relationship among culture, natural environment and economic aspects have been the key components to ensure the sustainability of tourism development. 


\section{Acknowledgments}

The authors would like to thank the community leaders of villages in Bali Tengah areas who were willing to take part in this study. We also send our deepest thanks to the colleagues who offered a lively discussion and critical feedback.

\section{REFERENCES}

Adhika, I.M. (2012). Komodifikasi kawasan suci Pura Uluwatu [Commodification of the sacred area of Uluwatu Temple], Udayana University Press, Denpasar, Indonesia.

Adiyoso, W. (2009). Menggugat perencanaan partisipatif dalam pemberdayaan masyarakat [Sues participatory planning in community empowerment], ITS Press, Jakarta, Indonesia.

Agung, A.A.P., Aryani, N.K., \& Jie, F. (2015). The influence of ecotourism development of Jatiluwih Village in Tabanan Regency of Bali Province to the development of economy, social culture and environment. International Journal of Information, Business and Management, 7(1), 324-348.

Agung, I.A.A.G. (1991). Bali in the 19th century, Yayasan Obor Indonesia, Jakarta, Indonesia.

Andreychouk, V. (2008). Evolution of the geographical environment and contemporary geography, Dissertations Commission of Cultural Landscape of PGS, 8, 5- 29.

Appadurai, A. (1986). The social life of things: commodities in cultural perspective, Cambridge University Press, Cambridge.

Appadurai, A. (2006). The thing itself. Public Culture, 18(1), 15-21.

Arinasa, I.B.K. (2010). Bamboo diversity and utilization in Balinese rituals at Angsri Village-Bali, Indonesia. Bamboo Science and Culture: The Journal of the American Bamboo Society, 23(1), 29-37.

Astawa, I.P., Sukawati, T.G.R., \& Sugiartha, I.N.G. (2019). Developing a harmonious culture-based sustainable event model in Bali Tourism Village. GeoJournal of Tourism and Geosites, 25(2), 446-462. https://doi.org/10.30892/gtg.25214-372

Bentivenga, M., Palladino, G., Prosser, G., Guglielmi, P., Geremia, F., \& Laviano, A. (2017). A geological itinerary through the Southern Apennine Thrust Belt (Basilicata-southern Italy). Geoheritage, 9, 1-17. https://doi.org/10.1007/s12371-015-0168-6

Birks, H.H., Birks, H.J.B., Kaland, P. \& Moe, D. (1989). The cultural landscape: Past, present and future, Cambridge University Press, Cambridge.

Borkhataria, R., Collazo, J.A., Groom, M.J. \& Garcia, A.J. (2012). Shade-grown coffee in Puerto Rico: Opportunities to preserve biodiversity while reinvigorating a struggling agricultural commodity. Agriculture, Ecosystems and Environment, 149, 164-170. https://doi.org/10.1016/j.agee.2010.12.023

Britton, S.G. (1982). The political economy of tourism in the third world. Annals of Tourism Research, 9, 331-358. https://doi.org/10.1016/0160-7383(82)90018-4

Buckley, R., Ollenburg, C. \& Zhong, L. (2008). Cultural landscape in Mongolian tourism. Annals of Tourism Research, 35(1), 47-61. https://doi.org/10. 1016/j.annals.2007.06.007

Burns, P.M. (2004). Tourism planning: a third way? Annals of Tourism Research, 31(1), 24-43. http://doi.org/10.1016/j.annals.2003.08.001

Burton, L.J. (2012). Building on living traditions: early childhood education and culture in Soloman Islands. Current Issues in Comparative Education, 15(1), 157-175.

Cebrián, F. \& Sánchez, I. (2016). The landscape as a tourist resource and its impact in mountain areas in the south of Castilla-La Mancha (Spain). International Journal of Sustainable, 11(3), 345-354. https://doi.org/10.2495/SDP-V11-N3-345-354

Chang, M.C.Y., Lee, P.Y. \& Yang, A.H. (2015). Cultural mobilization in reinvigorating the rural society in Taiwan: the case of the Wanbao community. Anthropologist, 22(1), 89-100. https://doi.org/10.1080/09720073.2015.11891860

Chapin, F S. (1957). Urban land use united governments of America, Harper \& Brothers Publisher, New York

Conzen, M. (2004). Cultural landscape in geography. In N. Smelser \& P. Bates (eds), International encyclopaedia of the social and behavioural sciences, 3086-3092, Elsevier, New York.

Costanza, R., d’Arge, R., de Groot, R., Farberk, S., Grasso, M., Hannon, B., Limburg, K., Naeem, S., O’Neill, R, V., Paruelo, J., Raskin, R.G., Suttonkk, P. \& van den Belt, M. (1997). The value of the world's ecosystem services and natural capital. Nature, 387, 253-260.

Covarrubias, M. (1974). Island of Bali, Oxford University Press, Kuala Lumpur.

Dalem, A.A.G.R. (2007). Filosofi tri hita karana dan implementasinya dalam industri pariwisata [Tri Hita Karana's philosophy and its implementation in the tourism industry]. In A.A.G.R. Dalem, I.W. Wardi, I.W. Suarna \& I.W.S. Adnyana (eds), Kearifan lokal dalam pengelolaan lingkungan hidup [Local wisdom in the environmental management]. UPT Penerbit and Pusat Penelitian Lingkungan Hidup Universitas Udayana, 81-94, Denpasar, Indonesia.

Degórski, M. (2005). Landscape as an objective visualization of some phenomena and processes carried out in geographical environmental megasystem. Dissertations Commission of Cultural Landscape of PGS, 4, 13-25 (in polish).

Domosh, M. (2004). Cultural landscape in environmental studies. In N. Smelser \& P. Bates, (eds), International Encyclopaedia of the Social and Behavioural Sciences, 3081-3086, Elsevier, New York.

Eiseman Jr.F.B. (1989). Sekala and niskala: essays on religious, ritual and art, I, Periplus Editions, Singapore.

Farina, A. (2000). The cultural landscape as a model for the integration of ecology and economics. BioScience, 50(4), 313-320. https://doi.org/10.1641/00063568(2000)050[0313:TCLAAM]2.3.CO;2

Freitag, T.G. (1994). Enclave tourism development: For whom the benefits roll? Annals of Tourism Research, 21, 538-554. https://doi.org/10.1016/0160-7383(94)90119-8

González, R.C. (2020). Some insights into the theory and practice of heritage ecology: grasping the bio-physical and socio-historical dynamism of the cultural landscape of Hangzhou. Documents d'Anàlisi Geogràfica, 66(1), 133-158. https://doi.org/10.5565/rev/dag.533

Gordon, J.E. (2018). Geoheritage, geotourism and the cultural landscape: enhancing the visitor experience and promoting geoconservation. Geosciences, 8(136), 1-25. https://doi.org/10.3390/geosciences8040136

Goris, R. (1984). The religious character of the village community. In JL Swellengrebel (ed), Bali: studies in life, thought and ritual, 77-100, Foris Publications, Doedrecht-Holland.

Gusfield, J.R. (1967). Tradition and modernity: misplaced polarities in the study of social change. American Journal of Sociology, 72(4), 351-362.

Hall, P.D. (2001) Culture, tourism and cultural tourism: Boundaries and frontiers in performances of Balinese music and dance. Journal of Intercultural Studies, 22(2), 173-187. https://doi.org/10.1080/07256860120069594

Herawati, N. (2015). Pengembangan pariwisata berkelanjutan berbasis subak sebagai bagian warisan budaya dunia Unesco Di Desa Mengesta Kabupaten Tabanan [Subak-based sustainable tourism development as part of Unesco's world cultural heritage in Mengesta Village, Tabanan Regency]. Jumpa, 2(1), 79 -103 (in Indonesia).

Hosany, S., Prayag, G., Deesilatham, S., Cauševic, S. \& Odeh, K. (2015). Measuring tourists' emotional experiences: Further validation of the Destination Emotion Scale. Journal of Travel Research, 54, 482-495. https://doi.org/10.1177/0047287514522878

Huang, H. \& Rockwell, J. (2019). Nature and the spirit: tri hita karana, sacred artistic practices, and musical ecology in Bali. EnviroLab Asia, 3 (2- article 20), 1-27. https://doi.org/10.5642/envirolabasia.20190302.02

Hussain, M.A., Yunos, M.Y.M., Ismail, N.A., Ariffin, N.F.M., \& Ismail, S. (2020). Review of the elements of nature and the Malay cultural landscape through Malay literature. Sustainability, 12, 1-13. http://doi.org/10.3390/su12062154

IBRD/IDA (1974). Bali tourism project, appraisal report, Tourism Projects Department, Washington.

Jaafar, M., Nordin, A.O. S., Abdullah, S., \& Marzuki, A. (2014). Geopark ecotourism product development: A study on tourist differences. Asian Social Science, 10(11), 42-55. http://dx.doi.org/10.5539/ass.v10n11p42

Jackson, J.B. (1984). Discovering the vernacular landscape, Yale University Press, New Haven, CT.

Kagami, H. (1988). Balinese traditional architecture in process, the Little World Museum of Man, Inuyama.

Kala, D. \& Bagri, S.C. (2018). Barriers to local community participation in tourism development: Evidence from mountainous state Uttarakhand,India.Tourism, 66(3), 318-333.

Liu, L.W. (2008). Reflections on community empowerment: Consideration of urban-rural differences, perspectives of urban development, and exploration of the bottom-up concept. City and Planning, 35(4), 313-338.

Mbaiwa, J.E. (2005). Enclave tourism and its socio-economic impacts in the Okavango Denta, Botswana. Tourism Management, 26, 157-172. https://doi.org/10.1016/j.tourman.2003.11.005

McGee, T.G. (1989). Urbanisasi or kotadesasi? Evolving urban patterns of urbanization in Asia. In F. J. Costa et al. (Eds), Urbanization in Asia, 93-108, University of Hawaii Press, Honolulu.

Meinig, D.W. (1979). The interpretation of ordinary landscapes, Oxford University Press, New York.

Munroe, D.K., McSweeney, K., Olson, J.L., \& Mansfield, B. (2014). Using economic geography to reinvigorate land-change science. Geoforum, 52, 12-21 https://doi.org/10.1016/j.geoforum.2013.12.005

Myga-Piątek, U. (2011). Cultural landscape of the 21st Century: Geographical Consideration between Theory and Practice. Hrvatski Geografski Glasnik, $73(2), 129-140$ 
Newsome, D., Dowling, R., \& Leung, Y.F. (2012). The nature and management of geotourismpp: A case study of two established iconic geotourism destinations. Tourism Management Perspectives, 2, 19-27. https://doi.org/10.1016/j.tmp.2011.12.009

Nurwasih, N.W. \& Wijaya, I.K.M. (2019). Setting ruang komunal di sepanjang Pantai Sanur, Bali [Communal space settings along Sanur Beach, Bali]. Arcade, 3(2), 108-116 (in Indonesia). https://doi.org/10.31848/arcade.v3i2.230

O'Hare, D. (1997). Interpreting the cultural landscape for tourism development. Urban Design International, 2(1), 33-54. https://doi.org/10.1057/udi.1997.5

Park, S. \& Santos, C.A. (2017). Exploring the tourist experience. A sequential approach. Journal of Travel Research, 56, 16-27. https://doi.org/10.1177/0047287515624017

Pawłowski, A. (2009). The sustainable development revolution. Problems of sustainable development, 4(1), 65-79 (in polish).

Petrosillo, I., Zurlini, G., Grato, E., \& Zaccarelli, N. (2006). Indicating fragility of socio-ecological tourism-based systems. Ecological Indicators, 6(1), 104-113. https://doi.org/10.1016/j.ecolind.2005.08.008

Picard, M. (1993). Cultural tourism in Bali: national integration and regional differention, in K Hitchcook \& Parnwell (eds), Tourism in South-East Asia, 7198, Routledge, London.

Picard, M. (1996). Bali: cultural tourism and touristic culture, Archipelago Press, Singapore.

Pietrzak, M. (2005). Evolution of geographical views of the landscape, in W. Maik, K. Rembowska, \& Suliborski (eds). Geography as science about space, environment, and landscape ,151-162, University of Toruń, University of Łódz, Lodzensias Society of Sciences, Łodź, Poland.

Pitana, I.G. \& Putra, I.G.S.A. (2013). Pariwisata sebagai wahana pelestarian subak, dan budaya subak sebagai modal dasar dalam pariwisata [Tourism as a vehicle for preservation of subak, and culture of subak as a basic capital in tourism]. Jurnal Kajian Bali, 3 (2), 159-180 (in Indonesian).

Pujaastawa, I.B.G., Wirawan, I.G.P. \& Adhika, I.M. (2005). Pariwisata terpadu alternatif model pengembangan pariwisata Bali Tengah [Integrated alternative tourism development model for Bali Tengah tourism], Universitas Udayana, Denpasar, Indonesia

Putra, I.D.G.A.D., Lozanovska, M. \& Fuller, R.J. (2019). From spiritualistic toward more pragmatic pattern: re-ordering Balinese houses and viability of the household traditions in tourism economy. Journal of Architecture and Urbanism, 43(1), 47-61. https://doi.org/10.3846/jau.2019.3692

Putra, I.D.G.A.D., Wirawibawa, I.B.G \& Satria, M.W. (2020). Spatial orientation and the patterns of the traditional settlement in the Eastern Bali: Investigating new tourism atractions. GeoJournal of Tourism and Geosites, 29(2), 663-667. https://doi.org/10.30892/gtg.29218-493

Putra, I.D.G.A.D. (2016). The tourism economy and viability of traditional settlements in the Balinese urban settings, The 3rd International Conference on Regional Development Enhancing Resilience: Bridging Knowledge and Policy for Cities and Regions, 61-67.

Putra, I.D.G.A.D. (2018). Evoking traditions and creating uniqueness: traditional settlements and tourism in disruptive era, Proceedings of the $4^{\text {th }}$ Biennale ICIAP (International Conference on Indinesia Architecture and Planning), Yogyakarta, p. 308-315.

Putra, I.D.G.A.D. (2019). The Impact of dynamic land-use and spatial planning policies on the traditional village and architecture in tourism villages in Gianyar Bali, Bhumi, 5(3), 34-41. https://doi.org/10.31292/jb.v5i3.388

Putri, I.D.A.H. (2014). Komunikasi ritual dalam kearifan lokal pelestarian "subak" di Bali [Ritual communication in the local wisdom of "subak" preservation in Bali]. In Nurudin, Komunikasi Budaya, Pariwisata dan Religi [Cultural, Tourism and Religious Communication]. p. 15-33, Astikom Press, Yogyakarta, Indonesia

Rapport, D.J., Costanza, R., \& McMichael, A. (1998). Assessing ecosystem health. Trends in Ecology \& Evolution, 13, 397-402. https://doi.org/ $10.1016 / \mathrm{S} 0169-5347(98) 01449-9$

Reuter, T. (2002). The house of our ancestors- precedence and dualism in highland of Balinese society, KITLV Press, Leiden.

Riadi, P.I., Wijayanti, F.L.R., Chafid, F., \& Hadi, P.R. (2018). Tourist decision in Mount Merbabu National Park, Indonesia. RJOAS, 3(75), 24-35. https://doi.org/10.18551/rjoas.2018-03.03

Rodenburg, E. (1980). The effects of scale in economic development: tourism in Bali. Annals of Tourism Research, 7(2), 177-196. https://doi.org/10.1016/0160-7383(80)90003-1

Salter, C. (1971). The cultural landscape. Duxbury, Belmont

Samsudin, P.Y. \& Maliki, N.Z. (2015). Preserving cultural landscape in homestay program towards sustainable tourism: brief critical review concept, Procedia-Social and Behavioral Sciences, 170, 433 - 441. https://doi.org/10.1016/j.sbspro.2015.01.004

Sanjiwani. PK., \& Pujani. L.P.K. (2019). Moratorium of sacred temple area as a tourist attraction, 3rd International Conference on Management \& Entrepreneurship (3rd i-CoME) Phuket, 25th - 27th July 2019.

Shaw, B. \& Shaw, G. (1999). Sun, sand and sales: enclave tourism and local entrepreneurship in Indonesia. Current Issues in Tourism, 2(1), 68-81. https://doi.org/10.1080/13683509908667844

Smith, L., \& Campbell, G. (2015). The elephant in the room: Heritage, affect and emotion. In W. Logan, M. N. Craith, \& U. Kockel (eds.), A companion to heritage studies, 443-460, Wiley Blackwell, Oxford UK.

Sprague, S. (1970). Bali: island of light, Kodansha Intrenational Ltd, Tokyo.

Taylor, K. (2015). Cities as cultural landscapes. In F. Bandarin \& R. van Oers (eds.), Reconnecting the City: The Historic Urban Landscape Approach and the Future of Urban Heritage, 179-202, Wiley-Blackwell, UK Oxford.

Tosun, C. \& Jenkins C.L. (1996). Regional planning approaches to tourism development: the case of Turkey. Tourism Management, 17(7), 519-531. https://doi.org/10.1016/S0261-5177(96)00069-6

Urry, J. \& Larsen, J. (2012). The tourist gaze 3.0, 3rd ed, SAGE Publications, London, UK

Utami, W. (2020). Resilience of cultural landscape heritage study in spatial tourism context, IOP Conf. Series: Earth and Environmental Science, 402, 1-8. https://doi.org/10.1088/1755-1315/402/1/012007

Vickers, A. (1989). Bali: a paradise created, Penguin Books Australia Ltd, Ringwood Victoria.

Wall, G. (1996). One name: two destinations: planned and unplanned coastal resorts in Indonesia. In L. Harrison and W. Husbands (eds), Practicing Responsible Tourism, 41-57, Wiley, Chichester.

Wardana, A. (2020). Neoliberalizing heritage: international agencies and the local dynamics of heritage conservation in Bali, Indonesia. In P. Peycam, S. L. Wang, H. Yew-Foong and H.H.M Hsiao, Heritage as Aid and Diplomacy in Asia, pp. 278-303, ISEAS-Yusof Ishak Institute, Singapore.

Wilson, M.A. \& Carpenter S.R. (1999). Economic valuation of freshwater ecosystem services in the United States: 1971-1997. Ecological Applications, 9, 751-783. https://doi.org/10.1890/1051-0761(1999)009[0772:EVOFES]2.0.CO;2

Wood, R.E. (1980). International tourism and cultural change in Southeast Asia. Economic Development and Cultural Change, 28(3), 561-81. https://doi.org/10.1086/451197

Wright, P.A. \& Matthews, C. (2015). Building a culture of conservation: Research findings and research priorities on connecting people to nature in parks. Parks, 21, 11-24.

Yamashkin, A.A., Yamashkin, S.A., Aksyonova, M.Y., Cimbaljevic, M., Demirovic, D., Vuksanovic, N., \& Milentijevic, N. (2020). Cultural landscapes spaces-temporal systematization of information in geoportals for the purposes of region tourist and recreational development. GeoJournal of Tourism and Geosites, 29(2), 440-449. https://doi.org/10.30892/gtg.29205-480

Yang, L. \& Wall, G. (2009). Ethnic tourism: a framework and an application. Tourism Management, 30, 559-570. https://doi.org/10.1016/j.tourman.2008.09.008

Yang, L., Wall, G. \& Smith, S.L.J. (2006). Ethnic tourism development: Chinese Government perspectives. Annals of Tourism Research, 35(3), 751-771. https://doi.org/10.1016/j.annals.2008.06.005

Yeny, I., Yuniati, D. \& Khotimah, H., (2016). Kearifan lokal dan praktik pengelolaan hutan bambu pada masyarakat Bali [Local wisdom and practice of bamboo forest management in the Balinese community]. Jurnal Penelitian Sosial dan Ekonomi Kehutanan, 13(1), 63-72 (in Indonesia).

Yudhiantari, L.P.E. (2002). Ekowisata sebagai alternatif dalam pengembangan pariwisata yang berkelanjutan di Desa Wongaya Gede, Kecamatan PenebelBali [Ecotourism as an alternative in the development of sustainable tourism in Wongaya Gede Village, Penebel-Bali District], Magister thesis, Diponegoro University, Semarang, Indonesia.

Zhang, R. \& Taylor, K. (2019). Cultural landscape meanings. The case of West Lake, Hangzhou, China, Landscape Research. https://doi.org/ $10.1080 / 01426397.2019 .1589438$

*** SCETO (1971). Bali tourism study. Report to the Government of Indonesia, UNDP/IBRD, 6 Volumes, Paris.

*** UNESCO (2003). Preservation of cultural landscapes and the intangible cultural heritage in the Pacific Region, (23 May 2006). http://www.unesco.org

*** UNESCO (2005). Cultural landscapes in the 21st century: tourism and economics. Forum UNESCO 10th International Seminar, $11-16$ April, University of Newcastle, United Kingdom.

*** World Tourism Organization (2012). UNWTO World Tourism Barometer, 10, UNWTO Publisher, Madrid. 